\title{
Vanadium as an indicator of the impact of fuel oiled thermal power plants on the environment: paleolimnological reconstructions
}

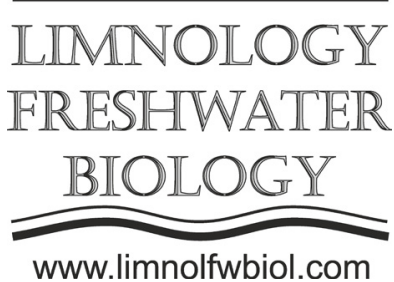

www.limnolfwbiol.com

\author{
Slukovskii Z.I. ${ }^{1,2 *}$, Guzeva A.V. ${ }^{1,3}$, Dauvalter V.A. ${ }^{1}$ \\ ${ }^{1}$ Institute of the North Industrial Ecology Problems of Kola Science Center of RAS, 184209 Apatity, Russia \\ ${ }^{2}$ Institute of Geology of Karelian Research Centre of RAS, 185910 Petrozavodsk, Russia \\ ${ }^{3}$ Institute of Limnology of the Russian Academy of Sciences, Sevastyanova str.,9, 196105, Saint Petersburg, Russia
}

\begin{abstract}
The article presents data on the behavior of vanadium in recent sediments from small urban lakes in the North of Russia. The works were carried out in Murmansk, Petrozavodsk and Monchegorsk. The main role in the entry of vanadium into the environment of these cities is played by emissions from thermal power plants operating on fuel oil.
\end{abstract}

Keywords: vanadium, thermal power plant pollution, small lakes, urbanized areas, Arctic

\section{Introduction}

It is known that thermal power plants (TPP) have a negative impact on the environment. Thermal power plants operating on fuel oil or coal are the most dangerous for living organisms, including humans (Ganor et al., 1988; Mejia et al., 2007). Fly ash released from fuel oiled TPP usually contains 3-4\% nickel $(\mathrm{Ni})$ and $6-12 \%$ vanadium $(\mathrm{V})$. The northern cities, where fuel oiled TPPs are connected to the district heating system, are most affected by fly ash emissions. Murmansk, Monchegorsk, Kovdor, Petrozavodsk, Arkhangelsk, Vologda were examples of such cities in the North of Russia. At the same time, in many countries, including Russia, the concentrations of these metals are not controlled by any regulatory documents. The purpose of this work is to assess the variations of geochemical behavior of vanadium in recent sediments of small lakes in cities where fuel oiled TPPs have been operated or continue to be operated.

\section{Materials and methods}

The sediment cores of five lakes located in Murmansk, Monchegorsk, and Petrozavodsk were taken using the gravity sampler Limnos in 2017-2019. All core sediments were divided into 1-cm layers. For the analysis sediment samples were dried to an air-dried state at the room temperature and to an absolutely-dry state in an oven at the temperature of $110{ }^{\circ} \mathrm{C}$. Concentrations of $\mathrm{V}$ were measured by the ICP-MS method in the Institute of Geology KRS RAS (Petrozavodsk). To assess the total content of trace elements in sediments, including $\mathrm{V}$, open acid decomposition of samples was carried out using $\mathrm{HF}, \mathrm{HNO}_{3}$, and $\mathrm{HCl}$. Furthermore, the geoaccumulation index $\left(\mathrm{I}_{\text {geo }}\right)$ of $\mathrm{V}$ in the sediments of each lake was calculated.

\section{Results and discussion}

Analysis of the sediment cores of lakes in northern cities revealed an increase in vanadium concentrations from the lower (background) layers of sediments to the upper ones formed during the industrial period. The highest concentrations of this metal (up to $4785 \mathrm{mg}$ / $\mathrm{kg}$ ) were found in the recent sediments of Lake Lamba in Petrozavodsk. This lake is located just $1 \mathrm{~km}$ from TPP which worked on fuel oil from 1976 to the 2000s. Since the 2000s, the TPP switched to natural gas. Therefore, ash emissions were axed. It was observed in the distribution of vanadium in the sediment core of Lake Lamba. The maximum concentration of this metal was identified in the layer $8-12 \mathrm{~cm}$. According to the geoaccumulation index, the sediments of Lake Lamba are characterized as strongly and extremely polluted $\left(I_{\text {geo }}=3.0-6.6\right.$ for layers of $0-16 \mathrm{~cm}$ ).

Lakes Semenovskoe, Okunevoe, and Severnoe located within the Murmansk are less polluted with vanadium. However, the uppermost layers of the sediments of these lakes $(0-4 \mathrm{~cm})$ are enriched with vanadium (fig. 1) because the Murmansk TPP still uses fuel oil (Slukovskii et al., 2020). For sediment layers $(0-16 \mathrm{~cm})$ of Murmansk's lakes, the values of the $I_{\text {geo }}$ index ranges from 1.2 to 4.2 (Lake Semenovskoe), from -0.3 to 3.6 (Lake Okunevoe), and from 1 to 3.5 (Lake Severnoe). In general, the sediments of these lakes can

*Corresponding author.

E-mail address: slukovsky87@gmail.com (Z.I. Slukovskii)

(C) Author(s) 2020. This work is distributed under the Creative Commons Attribution 4.0 License. 


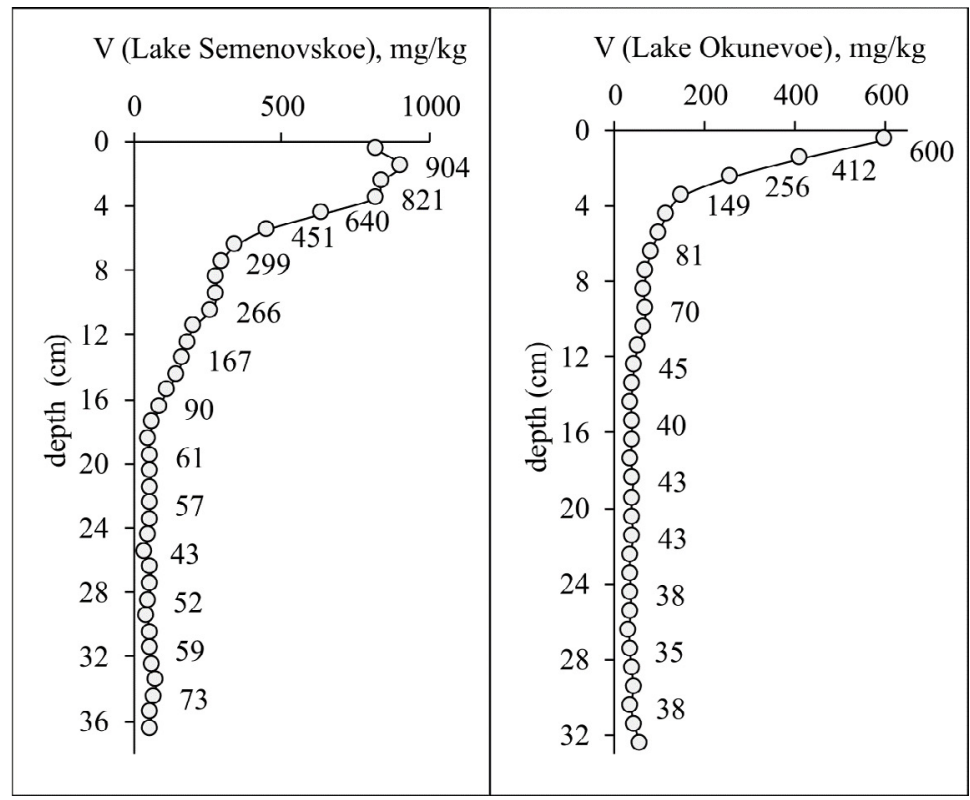

Fig.1. Vertical distribution of vanadium in the recent sediments of lakes Semenovskoe and Okunevoe (Murmansk)

be classified as moderately and strongly polluted by vanadium.

In the uppermost layers of sediments of Lake Komsomolskoe (the center of the Monchegorsk) also the excess of geochemical background was observed for $\mathrm{V}$. The TPP of Monchegorsk is located outside the city, on the territory of the Kola Mining and Metallurgical Company. Concentrations of vanadium in the sediments of Lake Komsomolskoe vary from 26 to $140 \mathrm{mg} / \mathrm{kg}$. According to the $\mathrm{I}_{\mathrm{geo}}$, the sediments are characterized as moderately polluted.

It should also be noted that vanadium concentrations in all lakes are closely correlated with nickel concentrations. Both metals can enter the urban environment as a result of emissions from fuel oiled TPP. The main form of vanadium in the sediments of studied urban lakes is the mineral phase. However, organic matter and iron hydroxides also play a significant role in the binding of vanadium.

\section{Conclusion}

Analysis of the accumulation of vanadium in the sediments of the urban lakes of Petrozavodsk, Murmansk, and Monchegorsk showed that the metal significantly accumulates in the upper layers of sediments as a result of the operation of fuel oiled TPPs. The most polluted were the sediments of Lake Lamba in Petrozavodsk. However, the Petrozavodsk TPP currently operates on natural gas, and the vanadium concentration is reduced. Murmansk's small lakes are less polluted with vanadium, but the TPP of Murmansk continues to operate on fuel oil and emit vanadiumenriched ash into the environment.

\section{Acknowledgements}

This research is supported by the Russian Science Foundation [project no. 19-77-10007] (analysis of total concentrations of vanadium in sediments of Murmansk's lakes) and the Russian Foundation for Basic Research [project no. 18-05-00897] (analysis of different forms of vanadium and total concentrations of vanadium in sediments of lakes in Petrozavodsk and Monchegorsk).

\section{References}

Ganor E., Altshuller S., Foner H.A. et al. 1988. Vanadium and nickel in dustfall as indicators of power plant pollution. Water, Air, and Soil Pollution 42: 241-252.

Mejia J.A., Rodriguez R., Armienta A. 2007. Aquifer Vulnerability Zoning, an Indicator of Atmospheric Pollutants Input? Vanadium in the Salamanca Aquifer, Mexico. Water, Air, and Soil Pollution 185: 95-100. https://doi.org/10.1007/ s11270-007-9433-x.

Slukovskii Z., Dauvalter V., Guzeva A. et al. 2020. The Hydrochemistry and Recent Sediment Geochemistry of Small Lakes of Murmansk, Arctic Zone of Russia. Water 12: 1130. https://doi.org/10.3390/w12041130 